\title{
Taxa de câmbio real e déficits gêmeos na economia monetária: relações de causalidade
}

\author{
Marco Flávio da Cunha Resende* \\ Fabrício de Assis Campos Vieira*
}

\begin{abstract}
RESUMO - Não há consenso na literatura econômica sobre as causas do déficit em transações correntes. Duas causas são frequentemente apontadas: a apreciação da taxa de câmbio real e o excesso de absorção doméstica, geralmente causado pelo déficit público. Argumenta-se neste estudo que seria um falso dilema a controvérsia sobre as causas do déficit em transações correntes. Pretende-se demonstrar que o déficit público pode causar o déficit em transações correntes porque provoca a apreciação da taxa de câmbio real. Demonstra-se neste artigo, também, que a relação entre déficit público, taxa de câmbio real e déficit externo se dá no âmbito do circuito Finance-Investimento-Poupança-Funding para economias abertas. Assim sendo, o déficit público não pode causar uma insuficiência de poupança nacional visto que a precedência do investimento em relação à poupança permanece válida.
\end{abstract}

Palavras-chave: Déficit público. Câmbio real. Déficit externo. Circuito Finance-InvestimentoPoupança-Funding.

\section{INTRODUÇÃO}

Não há consenso na literatura econômica sobre as causas do déficit em transações correntes. Duas causas são frequentemente apontadas: a apreciação da taxa de câmbio real implica alteração de preços relativos (bens comercializáveis versus bens não comercializáveis), afetando os saldos comerciais e em conta corrente do balanço de pagamentos, e o argumento de que o déficit público resulta em déficit em transações correntes do balanço de pagamentos porque o desequilíbrio das contas públicas implica excesso do investimento sobre a poupança nacional; isto resulta em absorção de poupança externa (déficit em transações correntes), necessária para compensar a insuficiência de poupança nacional - a tese dos déficits gêmeos. Porém, os mecanismos através dos quais o déficit público causa um déficit externo não são, em geral, demonstrados nos estudos sobre o tema.

Sobre este assunto, Krugman (1992, p. 24) argumenta que há uma conclusão definitiva e uma probabilidade. "A redução de desequilíbrios externos requer depreciação do câmbio real nos países deficitários e apreciação do câmbio real nos países superavitários, e isto é definitivo”.

\footnotetext{
*Doutor em economia pela Universidade de Brasília. É professor adjunto da Universidade Federal de Minas Gerais. Endereço eletrônico: resende@cedeplar.ufmg.br.

${ }^{* *}$ Mestre em economia pela Universidade Federal de Uberlândia. É professor substituto do Centro Federal de Educação Tecnológica de Minas Gerais. Endereço eletrônico: fvieira@cedeplar.ufmg.br.
} 
Porém, a contribuição dos desequilíbrios fiscais para ampliar os desequilíbrios externos seria apenas uma probabilidade, segundo aquele autor. De outro lado, autores como McKinnon (1984) e Giambiagi e Amadeo (1990) argumentam que hiatos de poupança-investimento são diretamente refletidos na balança comercial, sem necessidade de alteração dos preços relativos ${ }^{1}$. A esse respeito, Pastore e Pinotti (1995, p. 140) consideram que:

Estabelecer se as flutuações do câmbio real são menos importantes do que as variações do excesso de absorção sobre o produto na determinação da magnitude dos saldos comerciais, no entanto, é uma questão empírica, com as evidências favorecendo a importância relativa da taxa cambial. (PASTORE; PINOTTI, 1995).

Ainda, "Investigações empíricas recentes sobre a relação entre os déficits orçamentário e comercial geraram resultados dúbios" (VAMVOUKAS, 1999, p. 1093).

No âmbito da relação entre déficit púbico, deterioração da poupança nacional e déficit em conta corrente há, ainda, outra controvérsia. Esta diz respeito à relação de causalidade entre poupança e investimento. Keynes (1988; 1988a, 1988b) demonstrou a precedência temporal do investimento em relação à poupança para o caso da economia fechada no âmbito do circuito Finance-Investimento-Poupança-Funding ${ }^{2}$. Se este argumento for válido também para a economia aberta, então não poderia haver restrição de poupança nacional em relação ao investimento, pois é este que precede aquela.

O objetivo deste artigo é investigar a hipótese de que seria um falso dilema a controvérsia sobre as causas do déficit em transações correntes, isto é, a apreciação da taxa de câmbio real e o desequilíbrio fiscal do setor público não seriam duas causas distintas, ou separadas, do déficit externo. Argumenta-se neste estudo que o déficit público pode causar o déficit em transações correntes porque provoca a apreciação da taxa de câmbio real, ensejando, por meio deste mecanismo, uma insuficiência de poupança nacional.

Um segundo objetivo deste artigo é demonstrar que este mecanismo de determinação do déficit em transações correntes se dá no âmbito do circuito Finance-Investimento-Poupança-Funding, quando se considera o referencial teórico pós-keynesiano. Ou seja, partindo deste referencial pretende-se demonstrar que o déficit público pode provocar a apreciação da taxa de câmbio real e o déficit externo, embora o investimento continue precedendo a poupança. Neste caso, o investimento, que é contabilmente igual à soma da poupança nacional e da absorção de poupança externa, produzirá estímulos para a formação tanto da poupança nacional como também da poupança do resto do mundo que será objeto de absorção por meio do déficit em 1 Giambiagi e Amadeo (1990) explicitam que isto ocorre quando há pleno emprego dos fatores de produção. 2 Sobre o circuito Finance-Investimento-Poupança-Funding, ver Studart, cap. 4. 
conta corrente. Novamente, o mecanismo através do qual este processo se verifica é a alteração de preços relativos (mudança da taxa de câmbio real).

Além desta introdução, o artigo conta com outras três seções. Na Seção 2 serão explicitadas as relações entre déficit público, taxa de câmbio real, poupança nacional e déficit em transações correntes. Na seção seguinte será demonstrada a validade do circuito Finance-Investimento-Poupança-Funding para economias abertas. Será demonstrado, também, o mecanismo através do qual o déficit público produz vazamentos (para o resto do mundo) do estímulo à formação de poupança que decorre do investimento, no âmbito do circuito. Ou seja, o déficit público reduz o estímulo dado pelo investimento para a formação de poupança nacional compensando exatamente o desvio (aumento) do estímulo em direção à formação de poupança no resto do mundo. A quarta seção destina-se às considerações finais do trabalho.

\section{O DILEMA SOBRE AS CAUSAS DO DÉFICIT EM TRANSAÇÕES CORREN- TES}

Há muita confusão na literatura a respeito das causas dos déficits em transações correntes (CC). Pastore e Pinotti (1995) identificam duas causas possíveis: o excesso de absorção doméstica, muitas vezes causado pelo déficit público, e a apreciação da taxa de câmbio real. No primeiro caso, o déficit público causaria o déficit em CC porque provocaria a insuficiência da poupança nacional em relação ao investimento (tese dos déficits gêmeos). Este argumento é em geral demonstrado por meio da seguinte identidade macroeconômica ${ }^{3}$ :

$$
C C=S_{N}-I
$$

Ou, então:

$$
C C=Y-E=S^{P}-(G-T)-R L E E-I
$$

onde: $C C=$ saldo em conta corrente; $Y=$ renda nacional; $E=$ despesa agregada; $S^{P}=$ poupança privada agregada; $I=$ investimento agregado; $T=$ receitas correntes do governo; $G=$ gastos correntes do governo; $T-G=$ poupança pública; $S_{N}=$ poupança nacional $=S^{P}+(T-G)$ RLEE; RLEE = renda líquida enviada ao exterior.

Porém, as identidades das Contas Nacionais (CN) têm uma natureza contábil: as va-

3 Ver, por exemplo, Baharumshah et al. (2005), Vamvoukas (1999), Krugman (1992), Feldstein (1992), Rosensweig e Tallman (1993), Oskooee (1995), Giambiagi \& Amadeo (1990), Amadeo (1995), Resende (1995). 
riações de estoque são contempladas, desejadas ou não. As Contas Nacionais representam uma situação de “equilíbrio macroeconômico expost". Portanto, a identidade supracitada "não é uma teoria econômica ou uma regularidade empírica, mas uma identidade contábil sobre a qual não pode haver nenhum debate” (FELDSTEIN, 1992, p. 4). Ainda, “[...] olhar para as identidades nunca pode ser a análise completa. Devemos perguntar como a identidade contábil é traduzida em incentivos que afetam o comportamento individual” (KRUGMAN, 1992, p. 5) 4

"O vínculo entre desequilíbrios orçamentários e desequilíbrios comerciais é muito fraco" (KRUGMAN, 1992, p. 4). Em primeiro lugar, o desequilíbrio fiscal pode apenas deslocar gastos privados (crowding out) e/ou estimular a poupança privada (Equivalência Ricardiana), sem afetar, portanto, o saldo em CC. Em segundo lugar, não estão claros os mecanismos através dos quais um excesso da absorção doméstica sobre a produção nacional deterioraria o saldo em CC. Segundo Krugman (1992), mudanças no CC dependem de alterações na distribuição dos gastos mundiais, sendo que tais alterações dependem de mudanças na taxa de câmbio real. Krugman (1992, p. 14) demonstra que a correção do desequilíbrio em CC num contexto de pleno emprego só é viável mediante mudanças na taxa de câmbio real ${ }^{5}$.

É comum o argumento de que o desequilíbrio das contas públicas implica excesso do investimento sobre a poupança nacional. Isto resulta em absorção de poupança externa (déficit em CC), necessária para compensar a insuficiência de poupança nacional. Ou seja, o investimento corresponde ao aumento do estoque de capital físico da economia (formação bruta de capital fixo mais variação de estoques) (SIMONSEN; CYSNE, 1995, p. 151) e, em equilíbrio macroeconômico (ex post), é contabilmente igual à soma das poupanças nacional e externa (FEIJÓ et al., 2001, p. 8). Assim, a poupança nacional é a renda nacional não consumida e está associada à produção de capital que irá satisfazer a demanda de investimento. Se o déficit público implica aumento do consumo para um dado nível de renda, argumenta-se que haverá redução da taxa de poupança nacional, isto é, insuficiência de poupança nacional para um dado nível de investimento (RESENDE, 1995). O excesso do investimento agregado em relação à poupança nacional estaria associado a um déficit em conta corrente (absorção de poupança ex-

4 "A contabilidade nacional [...] não passa de um aglomerado de tautologias [...] As explicações da inflação e do déficit de transações correntes pelo déficit público, acima apresentadas, pecam exatamente pela extrema pobreza das hipóteses de comportamento [...] as relações entre causa e efeito são muito mais complexas do que o simples instrumental da contabilidade nacional pode revelar." (SIMONSEN; CYSNE, 1995, p. 165).

$5 \mathrm{O}$ autor demonstra que apenas em uma situação teórica, que não prevalece na prática, seria possível corrigir o desequilíbrio em conta corrente de uma economia em pleno emprego apenas através da redistribuição dos gastos mundiais. Porém, o modelo de Krugman (1992) pode ser refinado supondo dois setores: o de bens comerciáveis e o de não comerciáveis. Nesse caso, a redistribuição dos gastos mundiais, por maior que seja, não corrige tal desequilíbrio num contexto de pleno emprego, fazendo-se necessária uma mudança de preços relativos para o alcance deste objetivo. 
terna). Todavia, os mecanismos através dos quais este processo se manifestaria não são claros.

Tavares et al. (1982, p. 35) argumentam que tal processo não é concretamente possível visto que em certo momento do tempo o estoque de capital da economia está dado. Deste modo, o aumento da absorção doméstica não pode transformar bens de capital destinados à produção de capital em bens de capital destinados à produção de bens de consumo, e vice-ver$\mathrm{sa}^{6}$. Neste caso, o déficit público não reduz a disponibilidade interna de máquinas e equipamentos requeridos para o investimento e, então, seriam falaciosas as relações entre déficit público e insuficiência de poupança nacional, e entre déficit público e déficit externo.

Todavia, o argumento de Tavares et al. (1982) só é válido para economias fechadas. Se alterações na absorção doméstica vierem acompanhadas de mudanças dos preços relativos haverá mudanças na oferta de bens de investimento, alterando a poupança nacional, em economias abertas. Através da depreciação (apreciação) da taxa de câmbio real a poupança nacional pode ser ampliada (reduzida) ${ }^{7}$.

Há dois efeitos distintos relacionados à mudança da taxa de câmbio real. Segundo Pastore e Pinotti (1995, p. 141), o aumento relativo dos preços dos bens comerciáveis (BC) estimula a substituição do consumo em direção aos não comerciáveis (BNC), ao mesmo tempo em que estimula o aumento da produção daqueles, ampliando o excedente exportável.

Resultado semelhante também é obtido quando se trabalha com um modelo de fixação de preços segundo a regra de mark-up, e onde a economia não opera necessariamente a pleno emprego ${ }^{8}$. O aumento do preço no setor de $\mathrm{BNC}$ em relação ao setor de $\mathrm{BC}$ pode eliminar produtores de $\mathrm{BC}$ menos eficientes por meio do esmagamento de suas margens de lucro decorrente do aumento de custos de produção - aumento de preços de BNC. Do mesmo modo, a queda do preço relativo de BNC viabiliza a entrada de produtores menos eficientes no setor de BC.

O aumento dos preços dos BC em relação aos preços dos BNC resulta, então, em aumento do saldo comercial. A elevação das exportações líquidas (de importações) corresponde contabilmente à ampliação da poupança nacional ${ }^{9}$. Portanto, máquinas que produzem bens de

6 "A abstinência do trabalhador [...] não pode converter-se em poupança efetiva [...] Isto pela simples razão de que, da banana ao feijão preto, do rádio de pilha ao tevê em cores, nenhum desses produtos postos à margem do consumo pode transmutar-se, num passe de mágica, no cimento, no aço ou no projeto de engenharia que irão constituir a base real do investimento." (TAVARES et al., 1982, p. 35).

7 "Não há nenhum canal direto pelo qual a relação poupança-investimento é refletida de alguma maneira no saldo comercial sem afetar a taxa de câmbio real." (KRUGMAN, 1992, p. 24).

8 Sobre o modelo de mark-up ver, por exemplo, Kandir (1989) e Pereira (1999).

9 "A desvalorização aumenta o preço e reduz a demanda pelos bens chamados comerciáveis. Cai, portanto, o consumo desses bens e aumenta a poupança interna. Eis por que o saldo em conta corrente melhora." (RESENDE, 1995, p. 135). 
consumo não podem se metamorfosear em máquinas produtoras de bens de investimento, porém, os bens de consumo exportados geram divisas externas para importar bens de capital.

O aumento da absorção doméstica acima de uma dada taxa de crescimento do produto potencial, quando acompanhado de apreciação da taxa de câmbio real, reduz as exportações líquidas, inibindo a oferta de bens de investimento (bens de capital) que ocorre por meio de importações, num contexto de equilíbrio externo. Para que tal oferta não se reduza, torna-se necessário manter o nível das importações de bens de capital, apesar da queda das exportações líquidas, deteriorando-se o saldo em conta corrente.

Assim, supondo que déficits públicos implicam em aumentos na absorção doméstica (ausência de crowding out e de Equivalência Ricardiana), a questão-chave é saber se o aumento da absorção doméstica resulta em apreciação da taxa de câmbio real, necessariamente. Tal apreciação levará a uma insuficiência de poupança nacional em relação a um dado nível de investimento ${ }^{10}$.

A relação entre déficit público e alterações de preços relativos já está estudada em Resende (2009) e Rosensweig e Tallman (1993). Estes autores demonstraram por meio do modelo Mundell-Fleming que o déficit púbico pode provocar a apreciação da taxa de câmbio real. Resultado semelhante é encontrado em Feldstein (1992) para o caso de taxas de câmbio flexíveis. O primeiro autor demonstrou, também, que não há uma relação de causalidade sistemática entre déficit público e apreciação da taxa de câmbio real, mesmo quando se considera a ausência de Equivalência Ricardiana e de crowding out ${ }^{11}$. Isto é, não é sempre que o déficit público produz apreciação da taxa de câmbio real e déficit externo e, portanto, nem sempre prevalece a tese dos déficits gêmeos ${ }^{12}$.

Isto posto, é um falso dilema a controvérsia sobre as causas do déficit em CC, quais sejam, a apreciação da taxa de câmbio real e o excesso de absorção doméstica - sendo tal excesso muitas vezes causado pelo déficit público. Este último pode ensejar o déficit em CC quando provoca a apreciação da taxa de câmbio real ${ }^{13}$. A apreciação cambial, por sua vez, implicaria a 10 Krugman (1992), analisando os dados para a economia dos Estados Unidos, não encontrou evidências de uma relação sistemática entre estas variáveis. Evans (1986) encontrou evidências de que os déficits públicos norte americanos depreciam o dólar, ao invés de apreciá-lo. Estes resultados podem advir da ocorrência de crowding out e/ou Equivalência Ricardiana.

11 Sobre Equivalência Ricardiana e crowding out, ver, por exemplo, Seater (1993) e Krugman (1992).

12 Resende (2009) avaliou os efeitos do déficit público sobre a taxa de câmbio real quando estes são financiados por emissão monetária ou pelo aumento da dívida pública interna, quer em regime de taxa de câmbio fixa, quer flexível, seja com o produto em seu nível de pleno emprego ou aquém deste e num modelo onde são contemplados os setores de bens comerciáveis e não comerciáveis.

13 Frise-se que, enquanto o déficit público pode provocar a apreciação da taxa de câmbio real, esta nem sempre decorre do déficit público. É possível, por exemplo, que a política cambial produza apreciação cambial e déficit em CC, quer em um contexto de déficit público ou de superávit das contas do governo. Ademais, não é sempre que 
insuficiência de poupança nacional para uma dada taxa de investimento e também a deterioração do saldo em CC. Mas esta última seria o resultado da insuficiência de poupança nacional ou da apreciação cambial? Isto nos remete ao argumento pós-keynesiano, segundo o qual é o investimento que antecede a poupança e não o contrário.

\subsection{CÂMBIO, INVESTIMENTO E POUPANÇA}

A precedência do investimento em relação à poupança não é consensual na literatura econômica. $\mathrm{Na}$ abordagem pós-keynesiana não pode haver restrição de poupança ao investimento mesmo quando o déficit púbico leva à apreciação cambial e redução da poupança nacional, já que esta não antecede o investimento, necessariamente. Ademais, na economia fechada o investimento é sempre igual à poupança nacional, enquanto na economia aberta o investimento é sempre igual à soma da poupança nacional e da absorção de poupança externa.

Portanto, qual é a relação entre déficit público, investimento e poupança em economias monetárias abertas? Quando o déficit público implica apreciação da taxa de câmbio real, parcela da demanda de investimentos é deslocada para o exterior, afetando a taxa de poupança nacional ${ }^{14}$. O aumento do preço relativo dos bens não comerciáveis implica aumento da demanda doméstica por bens comerciáveis e redução da produção doméstica destes. Assim, a apreciação do câmbio real reduz a disponibilidade doméstica de bens de capital, entendida como a soma da produção doméstica de bens de capital destinada ao mercado interno e das importações destes bens até o ponto onde o saldo em transações correntes se equilibra. Após a apreciação da taxa de câmbio real torna-se necessário aumentar o volume de importação (de bens de capital) de modo a viabilizar dado volume de investimento, deteriorando-se o saldo em transações correntes. Então, a parcela do investimento total que corresponde à demanda de bens de capital satisfeita através da compra destes bens no mercado interno e da importação de bens de capital até o ponto onde o saldo em transações correntes se equilibra, se reduz após a apreciação da taxa de câmbio real, ensejando na mesma medida um menor volume de poupança nacional no âmbito do circuito Finance-Investimento-Poupança-Funding (F-I-S-F).

Quando a apreciação cambial ocorre, verificam-se, simultaneamente, deterioração do saldo em CC, queda da poupança nacional e reorientação para o exterior do estímulo à formação de poupança proporcionado pelo investimento. Estes três processos são faces da mesma o déficit público provoca a apreciação cambial, isto é, não há uma relação sistemática de causalidade entre déficit público e apreciação da taxa de câmbio real (RESENDE, 2009).

14 Há na abordagem pós-keynesiana vários canais através dos quais o déficit público afeta o investimento e que não são objeto de estudo neste trabalho. Trata-se da relação entre: déficit público e demanda efetiva, déficit público e melhora ou deterioração das expectativas dos agentes, déficit público e oferta de finance nacional e internacional, etc. 
moeda. Quando a taxa de câmbio real se aprecia as exportações líquidas caem. Assim, a parcela do investimento que corresponde às importações de bens de capital (BK), que antes da apreciação cambial estimulava a formação de poupança nacional através das exportações, passa a estimular a formação de poupança no exterior.

O investimento gera renda e, via multiplicador dos gastos, gera a poupança nacional na economia fechada. Na economia aberta, este papel do investimento também é exercido pelas exportações: a exportação gera renda e, via multiplicador, surge a poupança ${ }^{15}$. A receita das exportações é usada para a importação de BK, ou seja, tudo se passa como se as exportações fossem o próprio investimento doméstico (isto é, fossem a produção doméstica de BK), já que a receita das exportações é trocada por importação de $\mathrm{BK}^{16}$. Da mesma forma que ocorre com o investimento, as exportações geram renda, consumo e poupança nacional, apenas, ao invés de haver produção de BK para atender à demanda de investimento, haverá produção de bens destinados ao mercado externo e a receita destas exportações será usada para importar BK e, assim, satisfazer a demanda de investimento. Do mesmo modo que a produção de BK realizada para atender a demanda de investimento gera renda, consumo e poupança nacional no contexto do efeito multiplicador dos gastos, a atividade exportadora gera renda, consumo e poupança nacional, sendo esta última correspondente às exportações líquidas das importações de bens de consumo após deduzidos os gastos com a renda líquida enviada ao exterior (RLEE).

Quando a taxa de câmbio real se aprecia, surgem de modo simultâneo deterioração do saldo em CC e queda da poupança nacional, estando ambos os processos associados à contração das exportações líquidas. Contudo, se a magnitude do investimento não se alterar, a magnitude da despesa com BK também não se modificará. Uma vez que as exportações líquidas se reduziram após a apreciação cambial, não haverá mais a troca de bens exportados por importações de BK, pelo menos parcialmente. Isto é, parcela das importações de BK e, portanto, parcela do investimento, não terá mais correspondência na poupança nacional ${ }^{17}$. Após a apreciação cambial, parcela das importações de BK terá sua correspondência na absorção de poupança externa (déficit em CC). Do ponto de vista do resto do mundo (ou dos parceiros comerciais), suas exportações líquidas terão aumentado após a apreciação da taxa de câmbio 15 A atividade exportadora gera renda e parcela desta transforma-se em consumo e o restante é poupado, podendo ser exportado. Assim, as exportações fazem parte da poupança nacional quando não têm como contrapartida importação de bens de consumo.

16 Note que a parcela das exportações cuja receita é usada para importar bens de consumo não representa a poupança nacional.

17 Para facilitar a compreensão do argumento, suponha que antes da apreciação cambial a RLEE e as exportações líquidas (das importações) fossem zero. Após a apreciação cambial surge um déficit comercial, isto é, as exportações tornam-se menores do que as importações. A parcela das importações que excede as exportações não corresponde à poupança nacional, mas, sim, à absorção de poupança externa. 
real no país doméstico. Isto quer dizer que após a apreciação cambial parcela do investimento (importações de BK) do país doméstico passou a estimular a formação de poupança no resto do mundo e deixou de estimular a formação da poupança nacional no país doméstico.

Portanto, não se trata, neste caso, de insuficiência de poupança em relação a uma dada taxa de investimento. Partindo de um dado nível do investimento doméstico, quando há apreciação da taxa de câmbio real, surgem déficits em conta corrente estimulando a formação de poupança no resto do mundo a partir do investimento doméstico, enquanto o estímulo sobre a renda doméstica e sobre a poupança doméstica será reduzido. Este efeito do investimento sobre a formação da poupança nacional no contexto de apreciação da taxa de câmbio real pode ser constatado a partir da análise do circuito F-I-S-F para economias abertas.

\section{O CIRCUITO FINANCE-INVESTIMENTO-POUPANÇA-FUNDING NA ECO- NOMIA FECHADA}

O financiamento do investimento elaborado em Keynes (1988a, b) apresenta duas etapas: i) o investimento planejado (ex ante), quando a poupança ainda não foi criada via multiplicador, que corresponde ao crédito de curto prazo demandado pelas firmas no intervalo de tempo entre a decisão de investimento e sua implementação, visando financiar a produção de bens de capital (essa demanda de crédito foi denominada por Keynes de finance motive); ii) o investimento propriamente dito, ao qual corresponde uma poupança agregada que surge via multiplicador dos gastos.

O financiamento de curto prazo está ligado a um "fundo rotativo"18. O crédito associado ao finance encontra sua oferta nesse fundo. Ele é usado para estimular a atividade na indústria de bens de investimento, gerando, neste processo, uma renda através do multiplicador keynesiano ${ }^{19}$. Parte desta renda retorna ao sistema financeiro visto que não é usada para consu-

18 Detalhes em Keynes (1988b).

19 "Empresários devem ter os saldos monetários em mãos entre os períodos de pagamento relativo aos contratos de compra de insumos requeridos para a produção de bens de capital de modo a assegurar-se de que estão aptos a cumprir esses contratos. A quantidade de saldos monetários necessária em cada período para fazer face a esses contratos (pagamentos) futuros ligados à produção de bens de investimento permanecerá inalterada enquanto o investimento planejado também permanecer. Se, por exemplo, as expectativas de lucro crescerem exogenamente, [...] empresários demandarão bens de investimento adicionais [...] a demanda por moeda para pagar pela produção desses bens de investimento adicionais a qualquer nível de taxa de juros crescerá mesmo antes de qualquer emprego e renda adicionais terem sido gerados [...] é evidente do Tratado sobre a Moeda e das notas de Keynes de 1937 [...] sobre o motivo finanças, que, especificar a demanda por moeda como uma função direta da renda corrente é uma simplificação grosseira e errada de sua análise da liquidez.” (DAVIDSON, 1994, p. 122-123). Ainda: "Investimento é um processo no tempo e [...] envolve um complexo de pagamentos que precisa ser financiado [...] investimento em nossa economia é uma transação de troca de dinheiro agora por dinheiro mais tarde." (MINSKY, 1986, p. 214). 
mo, constituindo-se em poupança. Ao final desse processo, a poupança, resultante da despesa de investimento, é usada para transformar a dívida de curto prazo dos investidores junto ao sistema bancário em passivo de longo prazo. O funding corresponde a esse processo de "consolidar" a dívida de curto prazo, isto é, transformá-la numa relação de longo prazo através da emissão de ações e de títulos ${ }^{20}$. Assim, poupança e financiamento da despesa do investimento não se confundem, necessariamente ${ }^{21}$.

A taxa de juros, por sua vez, não depende da poupança, pois se constitui num fenômeno monetário e se relaciona inversamente com o investimento. Na economia monetária, a taxa de juros não é a retribuição "pela espera para consumir” e, sim, pela renúncia à liquidez. O juro é determinado pela preferência pela liquidez e pela oferta de moeda, esta última determinada pela política monetária e pelas estratégias de crédito dos bancos ${ }^{22}$. O conceito de preferência pela liquidez está associado ao conceito de incerteza ${ }^{23}$. Ademais, o investimento é sensível ao grau de incerteza e às expectativas a ele associadas, que, por seu turno, dependem das condições de finance e de funding do sistema, entre outros fatores ${ }^{24}$.

Este modus operandis da economia monetária de produção verifica-se porque nesta economia as concepções de moeda, de tempo e de incerteza são fundamentais. Estas concepções rompem com os axiomas neoclássicos, invalidando sua teoria e introduzindo novos fundamentos para a economia monetária, conforme demonstram Carvalho (1992a, b), Amado (2000) e Davidson (1992). Deste modo, em economias monetárias prevalece o circuito F-I-S-F. O investimento antecede a poupança que, por seu turno, resulta do crescimento econômico e se presta à consolidação da acumulação de capital.

20 Note, neste processo, a relevância da defasagem temporal existente entre o pedido feito à indústria de bens de capital, que corresponde à decisão de investir, e a maturação da produção dessa categoria de bens. Note, também, a relevância dos mercados secundários, visto que estes garantem liquidez para títulos de longo prazo. É a possibilidade de se desfazer desses títulos no curto prazo, por meio de suas vendas nos mercados secundários, que os tornam atrativos para os poupadores. Este seria o lado positivo desses mercados. O lado negativo corresponde à sua natureza especulativa, que pode provocar uma redução nos preços dos títulos (dado um aumento da preferência pela liquidez), em geral, deteriorando o nível de fragilidade financeira de todo o sistema econômico (MINSKY, 1986). 21 'Mas 'financiamento' nada tem a ver com poupança [...] 'Financiamento' e 'compromissos de financiamento' são simples entradas contábeis de crédito e débito, que facilitam aos empresários ir adiante com segurança.” (KEYNES, 1988b, p. 323).

22 Sobre o comportamento da firma bancária em economias monetárias, ver, por exemplo, Minsky $(1986,1992)$ e Paula (1999).

23 Sobre o caráter endógeno da oferta de moeda, ver Davidson (1994, p. 135-136) e Carvalho (1993). Sobre o conceito de incerteza, ver Amado (2000) e Carvalho (1992, a, b).

24 Conforme Keynes (1988, p. 101): “O leitor notará que a eficiência marginal do capital é definida aqui em termos da expectativa da renda e do preço de oferta corrente do bem de capital. Ela depende da taxa de retorno que se espera obter do dinheiro investido num bem recentemente produzido; e não do resultado histórico obtido por um investimento em relação a seu custo original, quando examinado retrospectivamente ao fim de sua vida." (grifo nosso). 
O circuito acima descrito foi originalmente formulado para economias fechadas. A seguir será demonstrada a validade do circuito F-I-S-F para economias abertas cujos saldos em CC não são equilibrados. Para realizar tal tarefa não é necessário que se esgote todos as situações possíveis, bastando que se apresente uma situação concreta onde o investimento precede a poupança. De todo modo, Resende (2008) desenvolveu, ainda, o caso onde a validade do citado circuito verifica-se também no contexto de economias com saldos em CC equilibrados. Por fim, serão demonstrados os mecanismos através dos quais a apreciação da taxa de câmbio real transfere o estímulo do investimento para a formação da poupança nacional em direção à formação de poupança no resto do mundo (parceiros comerciais).

\subsection{O CIRCUITO FINANCE-INVESTIMENTO-POUPANÇA-FUNDING NA ECONO- MIA ABERTA}

O circuito F-I-S-F para a economia fechada está representado na Figura 1, onde BCS $=$ bens de consumo e BK = bens de capital. $\mathrm{Na}$ economia fechada o circuito é caracterizado pela realização do finance, seguida da compra de BK e da geração de renda (inicial) no setor produtor desta categoria de bens. Parcela desta renda é então usada para consumo e o restante constitui-se em poupança no âmbito do processo multiplicador dos gastos. Ao final desse processo tem-se a poupança necessária para a realização do funding, completando-se o circuito F-I-S-F. Para o caso de economias abertas estas mesmas etapas são necessárias para o funcionamento do circuito, porém, o sistema financeiro internacional e o comércio internacional também fazem parte do mesmo.

FIGURA 1 - FINANCE-INVESTIMENTO-POUPANÇA-FUNDING EM ECONOMIAS FECHADAS

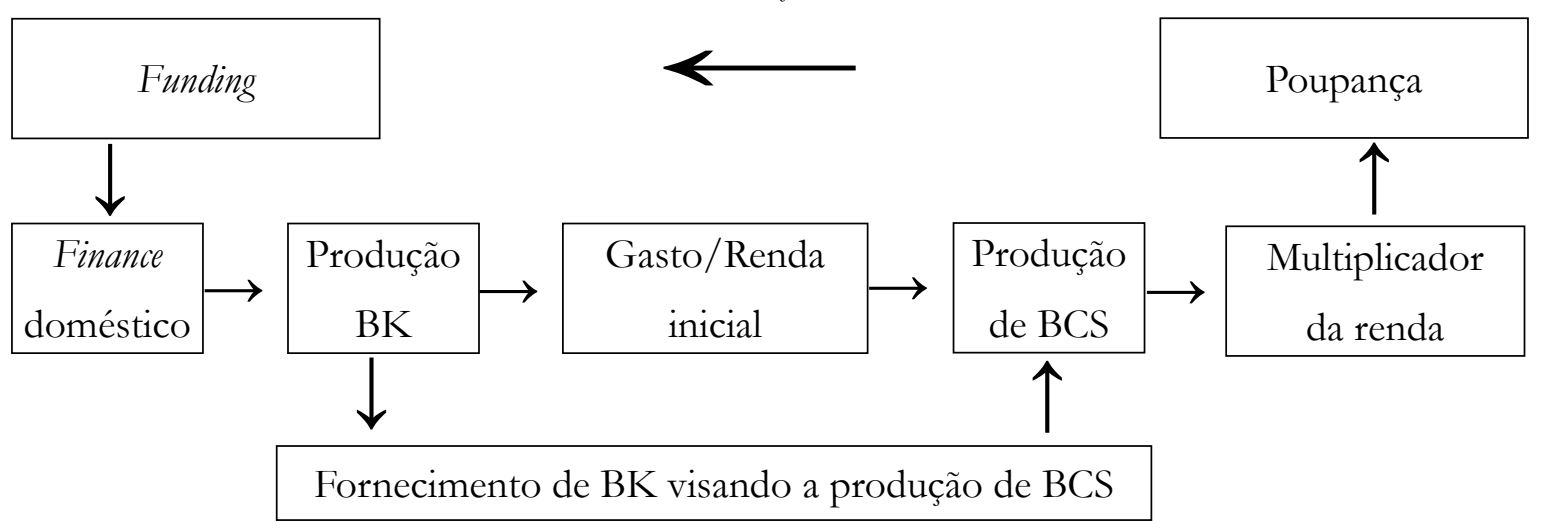

3.1.1 O caso de economias com desequilíbrio em transações correntes

Suponha duas economias abertas, o país Z e o resto do mudo, W. O saldo em CC encontra-se equilibrado em ambas as economias, sendo que W exporta BK e importa BCS, 
enquanto para $Z$ verifica-se exatamente o oposto. Em W a exportação de BK eleva-se e sua importação de BCS cai a zero, após ocorrer apreciação da taxa de câmbio real em Z decorrente, por exemplo, do déficit público neste país.

Após a apreciação do câmbio real em Z, o circuito F-I-S-F verificado em W é o mesmo daquele correspondente à economia fechada, a não ser pelo fato de que parcela da produção doméstica de BK não se destina ao mercado interno, sendo exportada. Neste caso, o consumo (real) induzido pela renda gerada na produção dos BK exportados, como também a expansão do produto real associada a este processo, só ocorrerá se o nível inicial do produto estiver aquém do nível de pleno emprego - há capacidade ociosa na indústria de BCS do país W de modo que esta pode prescindir dos BK exportados para aumentar sua produção ${ }^{25}$.

A renda inicial gerada na produção dos BK destinados à exportação induz o consumo interno e, via efeito multiplicador, a poupança surge como resíduo. Nesse processo, a renda não consumida corresponde à poupança cuja contrapartida são exportações de BK, isto é, superávit em conta corrente. A poupança proporciona os recursos financeiros necessários ao funding relacionado à produção de $\mathrm{BK}$ e, paralelamente, as exportações desses bens enseja um aumento das reservas externas do país $\mathrm{W}$, que podem ser usadas como oferta de crédito deste país à economia Z - visando o financiamento das importações de BK desta (Figura 2).

FIGURA 2 - PAÍS W

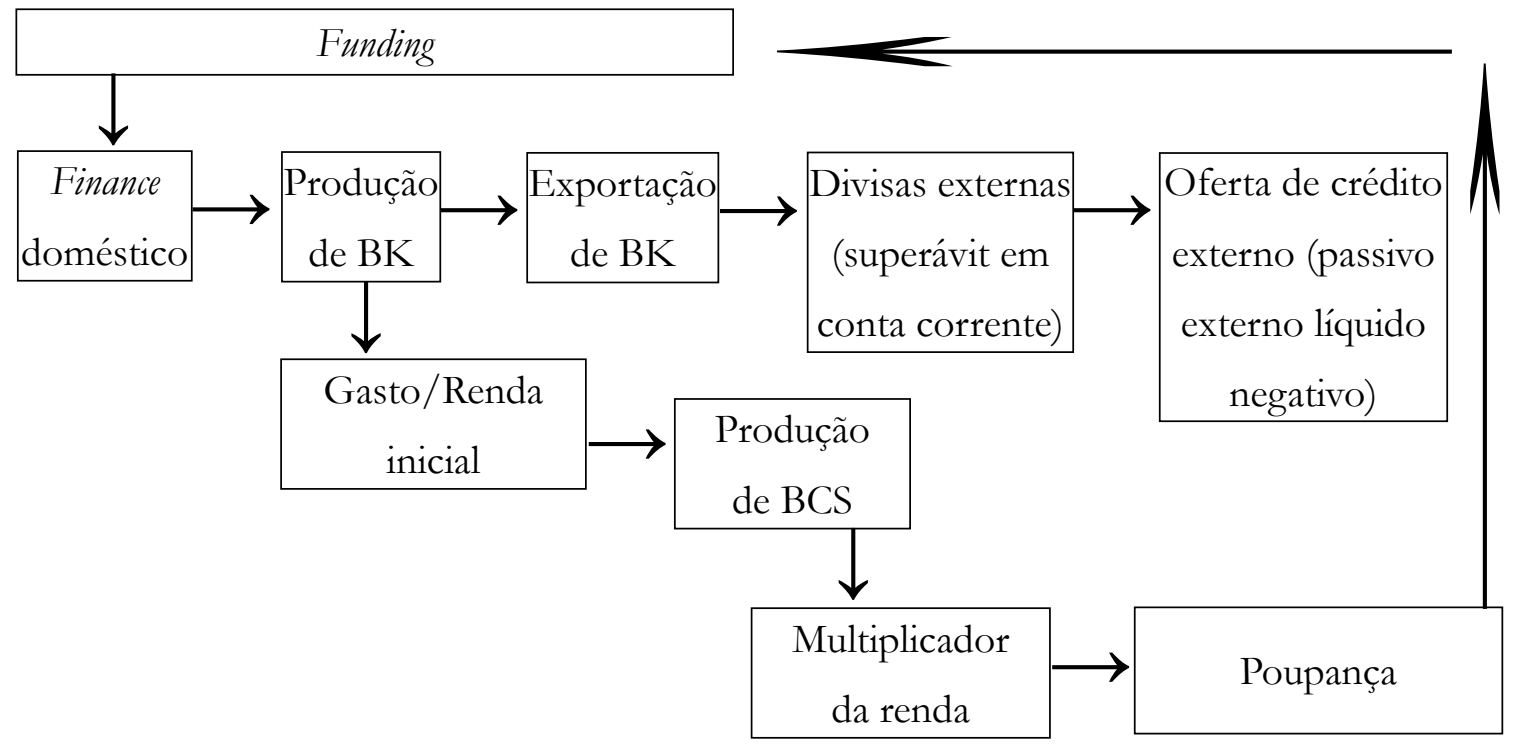

Exportação (líquida) de BK = Poupança $=$ Superávit em conta corrente

A mudança de preços relativos verificada inicialmente na economia $Z$ estimulou o

25 Esta hipótese pode ser relaxada quando a economia opera a pleno emprego, porém, uma depreciação da taxa de câmbio real em W amplia sua produção potencial de bens comerciáveis. 
aumento da produção de $\mathrm{BK}$ em W, mas tal tarefa exigiu inicialmente um finance no mercado doméstico, liquidado a partir da poupança que surgiu como resíduo do crescimento da renda. Em última instância, a apreciação da taxa de câmbio real em $Z$ estimulou a formação de poupança em W, ao mesmo tempo em que a produção de BK para exportação neste país (que corresponde ao investimento na economia Z) não necessitou de uma poupança prévia, mas, sim, de finance, prevalecendo o circuito F-I-S-F.

$\mathrm{Na}$ economia Z, após a apreciação da sua taxa de câmbio real, a produção de bens comerciáveis, inclusive de BK, é reduzida, enquanto a demanda doméstica por estes bens aumenta. Para simplificar o raciocínio, mas sem comprometer as conclusões da análise, digamos que toda exportação da economia $Z$ torna-se nula após a apreciação cambial. Mantendo-se a mesma magnitude do investimento em Z, as importações de BK aumentarão, realizadas por meio do finance no sistema financeiro internacional que, por sua vez, não é consolidado na ausência das exportações de BCS. Contudo, o restante do circuito F-I-S-F é semelhante àquele observado na economia fechada. Os BK importados são usados para produzir outros BK e há, para isso, um finance interno. Neste processo, a renda cresce e a poupança que consolidará o finance interno surge como resíduo. Em Z, o balanço de pagamentos permanece equilibrado no curto prazo, visto que às importações de BK correspondeu uma entrada de recursos externos pela Conta Financeira do balanço de pagamentos. Contudo, a economia $\mathrm{Z}$ passa a carregar um passivo externo, aumentando a vulnerabilidade de sua inserção internacional (Figura 3).

FIGURA 3 - PAÍS Z

\begin{tabular}{|c|c|c|c|}
\hline $\begin{array}{l}\text { Finance } \\
\text { externo }\end{array}$ & $\begin{array}{c}\text { Importação } \\
\text { de BK }\end{array}$ & $\begin{array}{c}\text { Déficit em } \\
\text { conta corrente }\end{array}$ & $\begin{array}{c}\text { Passivo externo } \\
\text { líquido }\end{array}$ \\
\hline
\end{tabular}

Investimento $=$ Importação de BK $=$ Déficit em conta corrente

Portanto, a precedência do investimento em relação à poupança permanece válida em economias abertas e em situação de desequilíbrio comercial, enquanto o circuito F-I-S-F é mais complexo e requer a participação dos mercados financeiros domésticos e internacionais. As relações débito-crédito são ampliadas, como também o são a coordenação dessas relações e a incerteza envolvida nesse processo, que, inclusive, engloba a possibilidade de mudanças na taxa de câmbio (DAVIDSON, 1992, p. 83-140; 1994, p. 223-237). Ademais, após a apreciação cambial em $Z$ o estímulo do investimento na economia $Z$ para a formação de poupança se transfere parcialmente do país Z para o país W. No país Z o excesso de investimento sobre a poupança 
resulta em déficit em conta corrente - isto é, absorção de poupança externa que surgiu em W após a apreciação da taxa de câmbio real em Z.

Em suma, quando o déficit público provoca uma mudança de preços relativos verifica-se um deslocamento (parcial) da demanda por bens de investimento do mercado doméstico para o mercado externo. Por conseguinte, parcela do estímulo do investimento para a formação de poupança se transfere para o resto do mundo, e, ex post, o investimento permanece sendo igual à soma da poupança nacional e da absorção de poupança externa.

\section{CONCLUSÃO}

O estudo da relação entre déficit público, insuficiência de poupança nacional e déficit em conta corrente requer o conhecimento dos mecanismos (ou incentivos) através dos quais o déficit público poderia reduzir a poupança nacional e estimular o déficit externo. Tais mecanismos (incentivos) não podem ser demonstrados por meio de identidades contábeis, pois estas não apresentam relações de causalidade.

$\mathrm{Na}$ economia fechada, dada a renda agregada, o déficit público não reduz a poupança nacional. Isto ocorre por que bens de capital que produzem bens de capital não podem se metamorfosear em máquinas produtoras de bens de consumo para atender às demandas de um governo perdulário. Todavia, na economia aberta, a apreciação da taxa de câmbio real pode ser consequência do déficit público (RESENDE, 2009), redundando em queda da poupança nacional e em déficit em conta corrente. Portanto, a mudança de preços relativos é o mecanismo por meio do qual o déficit público resulta em queda da poupança nacional para uma dada taxa de investimento. Além disso, demonstrou-se que a precedência do investimento em relação à poupança, no âmbito do circuito Finance-Investimento-Poupança-Funding, permanece válida na economia aberta. Neste caso, quando se verifica a apreciação da taxa de câmbio real, parcela do estímulo do investimento sobre a formação da poupança nacional é transferida para a formação de poupança no resto do mundo.

\section{REFERÊNCIAS}

AMADEO, E. J. Nem câmbio nem ajuste fiscal. Revista de Economia Política, São Paulo, v. 15, n. 2, abr./jun. 1995.

AMADO, A. M. Limites monetários ao crescimento: Keynes e a não neutralidade da moeda. Ensaios FEE, Porto Alegre, ano 21, n. 1, 2000.

BAHARUMSHAH, A. Z.; LAU, E.; KHALID, A. M. Testing twin deficits hypothesis: using VAR`s and variance decomposition. Economics Working Paper Archive at WUSTL, 2005.

CARVALHO, F. J. C. Mr. Keynes and the post-keynesians: principles of macroeconomics 
for a monetary production economy. Reino Unido: Edward Elgar, 1992a.

CARVALHO, F. J. C. Moeda, produção e acumulação: uma perspectiva pós-keynesiana. In: SILVA, M. L. F. (Org.) Moedas e produção: teoria comparadas. Brasília: UnB, 1992b.

CARVALHO, F. J. C. Sobre a endogenia da oferta de moeda: réplica ao professor Nogueira da Costa. Revista de Economia Política, São Paulo, v. 13, n. 3, jul./set. 1993.

CARVALHO, F. J. C.; SOUZA, F. E.P.; SICSÚ, J.; PAULA, L. F. R.; STUDART, R. Economia monetária e financeira: teoria e política. Rio de Janeiro: Campus, 2001.

DAVIDSON, P. International money and the real world. 2. ed. London: Macmillan, 1992.

DAVIDSON, P. Post-keynesian macroeconomic theory: a foundation for successful economic policies for the twenty-first century. Cambridge: Cambridge University Press, 1994.

EVANS, P. Is the dollar high because of large budget deficits? Journal of Monetary Economics, Houston, v. 18, n. 3, nov. 1986.

FEIJÓ, C. A.; RAMOS, R. L. O.; YOUNG, C. E. F.; LIMA, F. G. C.; GALVÃO, O. J. A. Contabilidade social: o novo sistema de Contas Nacionais do Brasil. Rio de Janeiro: Campus, 2001.

FELDSTEIN, M. The budget and trade deficits aren't really twins. NBER Working Paper, Cambridge, n. 3966, jan. 1992.

GIAMBIAGI, F; AMADEO, E. J. Taxa de poupança e política econômica: notas sobre as possibilidades de crescimento numa economia com restrições. Revista de Economia Política, São Paulo, v. 10, n. 1, jan./mar. 1990.

KANDIR, A. A dinâmica da inflação: uma análise das relações entre inflação, fragilidade financeira do setor público, expectativas e margens de lucro. São Paulo: Nobel, 1989.

KEYNES, J. M. A teoria geral do emprego, do juro e da moeda. São Paulo: Nova Cultural, 1988.

KEYNES, J. M. Teorias alternativas da taxa de juros. In: CLÁSSICOS da literatura econômica. Rio de Janeiro: IPEA/INPES, 1988a.

KEYNES, J. M. A teoria ex ante da taxa de juros. In: CLÁSSICOS da literatura econômica. Rio de Janeiro: IPEA/INPES, 1988b.

KRUGMAN, P. R. Currencies and crisis. Cambridge: MIT Press, 1992.

MCKINNON, R. An international standard for monetary stabilization. Washington: Institute for International Economics, 1984.

MINSKY, H. P. Stabilizing and unstable economy. New Haven: Yale University Press, 1986.

OSKOOEE, M. B. The long-run determinants of U.S. trade balance revisited. Journal of Post Keynesian Economics, New York, v. 17, n. 3, 1995.

PAULA, L. F. R. Teoria da firma bancária. In: LIMA,G. T.; SICSÚ, J.; PAULA, L. F. R. Macroeconomia moderna: Keynes e a economia contemporânea. Rio de Janeiro: Campus, 1999.

PASTORE, A. C.; PINOTTI, M. C. Taxa cambial real e os saldos comerciais. Revista de Economia Política, São Paulo, v. 15, n. 2, abr./jun. 1995.

PEREIRA, T. R. Endividamento externo e o ajuste financeiro da grande empresa industrial nos anos noventa. Dissertação (Mestrado em Economia) - Instituto de Economia da UNICAMP, Campinas, 1999. 
RESENDE, A. L. O México e o câmbio: tequila, câmbio e o velho cinismo. Revista de Economia Política, São Paulo, v. 15, n. 2, abr./jun. 1995.

RESENDE, M. F. C. O circuito finance-investimento-poupança-funding em economias abertas. Revista de Economia Política, São Paulo, v. 28, n. 1, jan./mar. 2008.

RESENDE, M. F. C. Déficits gêmeos e poupança nacional: abordagem teórica. Revista de Economia Política, São Paulo, v. 29, n. 1, jan./mar. 2009.

ROSENSWEIG, J. A.; TALLMAN, E. W. Fiscal policy and trade adjustment: are the deficits really twins? Economic Inquiry, New Jersey, v. 31, out. 1993.

SIMONSEN, M. H.; CYSNE, R. P. Macroeconomia. 2. ed. Rio de Janeiro: Fundação Getúlio Vargas, 1995.

STUDART, R. Investment finance in economic development. London: Routledge, 1995.

TAVARES, M. C.; ASSIS, J. C.; TEIXEIRA, A. A questão da poupança: desfazendo confusões. In: TAVARES, M. C.; DAVID, M. D. A economia política da crise. Rio de Janeiro: Vozes, 1982.

VAMVOUKAS, G. A. The twin deficits phenomenon: evidence from Greece. Applied Economics, Philadelphia, v. 31, n. 9, set. 1999. 